\title{
Dorsal Root Entry Zone Lesioning: Systematic Review
}

\section{Lesionamento da zona de entrada da raiz dorsal: Revisão sistemática}

\author{
Giovanna Zambo Galafassi ${ }^{10}$ Paulo Henrique Pires Aguiar ${ }^{2,3,4}$ André Akira Takahashi ${ }^{10}$ \\ Jorge Roberto Pagura ${ }^{5}$ \\ 1 Faculdade de Medicina do ABC, Santo André, SP, Brazil \\ 2 Department of Research and Innovation, Laboratório de Biologia Celular e \\ Molecular, Faculdade de Medicina do ABC, Santo André, SP, Brazil \\ ${ }^{3}$ Department of Neurosurgery, Hospital Santa Paula, São Paulo, SP, Brazil

\begin{abstract}
Address for correspondence Giovanna Zambo Galafassi, Faculdade de Medicina do ABC, Rua Pirassununga, 190, apto 42, Valparaíso, Santo André, SP, 09060020, Brazil (e-mail: giovannagalafassi@gmail.com).
\end{abstract}

${ }^{4}$ Department of Neurology, Pontifícia Universidade Católica de São

Paulo, Sorocaba, SP, Brazil

${ }^{5}$ Department of Neurology and Neurosurgery, Faculdade de Medicina do ABC, Santo André, SP, Brazil

Arq Bras Neurocir 2021;40(3):e229-e237.

\begin{abstract}
Keywords

- neuropathic pain

- dorsal root entry zone

- radiculopathy

- spinal cord
\end{abstract}

Resumo
Introduction Dorsal root entry zone (DREZ) leasioning (DREZ-otomy) is considered an effective treatment for chronic pain due to spinal cord injuries, brachial and lumbosacral plexus injuries, postherpetic neuralgia, spasticity, and other conditions. The objective of the technique is to cause a selective destruction of the afferent pain fibers located in the dorsal region of the spinal cord.

Objective To identify and review the effectiveness and the main aspects related to DREZ-otomy, as well as the etiologies that can be treated with it.

Methods The PubMed, MEDLINE and LILACS databases were used as bases for this systematic review, having the impact factor as the selection criteria. The 23 selected publications, totalizing 1,099 patients, were organized in a table for systematic analysis.

Results Satisfactory pain control was observed in $70.1 \%$ of the cases, with the best results being found in patients with brachial/lumbosacral plexus injury $(70.8 \%)$ and the worst, in patients with trigeminal pain (40\% to $67 \%$ ).

Discussion Most of the published articles observed excellent results in the control of chronic pain, especially in cases of plexus injuries. Complications are rare, and can be minimized with the use of new technologies for intraoperative monitoring and imaging. Conclusion DREZ-otomy can be considered a great alternative for the treatment of chronic pain, especially in patients who do not tolerate the side effects of the medications used in the clinical management or have refractory pain.

Introdução O lesionamento da zona de entrada da raiz dorsal (dorsal root entry zone, DREZ), ou DREZ-otomia, é considerado um tratamento eficaz para a dor crônica decorrente de lesões medulares, lesão dos plexos braquial e lombossacro, neuralgia received

May 4, 2020

accepted

August 24, 2020

published online

November 26, 2020
DOI https://doi.org/ 10.1055/s-0040-1719003. ISSN 0103-5355.

\footnotetext{
(c) 2020. Sociedade Brasileira de Neurocirurgia. All rights reserved. This is an open access article published by Thieme under the terms of the Creative Commons Attribution-NonDerivative-NonCommercial-License, permitting copying and reproduction so long as the original work is given appropriate credit. Contents may not be used for commercial purposes, or adapted, remixed, transformed or built upon. (https://creativecommons.org/ licenses/by-nc-nd/4.0/)

Thieme Revinter Publicações Ltda., Rua do Matoso 170, Rio de Janeiro, RJ, CEP 20270-135, Brazil
} 


\section{Palavras-chave}

- dor neuropática

- zona de entrada da raiz dorsal

- radiculopatia

- medula espinal pós-herpética, espasticidade, entre outras lesões. O objetivo da técnica é causar uma destruição seletiva das fibras localizadas na região dorsal da medula espinal, entre elas as fibras aferentes de dor.

Objetivo Identificar a efetividade da DREZ-otomia e as principais etiologias que podem ser tratadas por este procedimento, e revisar os principais aspectos relacionados à técnica.

Métodos As bases de dados do PubMed, MEDLINE e Lilacs foram utilizadas na realização desta revisão sistemática, tendo o impacto como critério de seleção. As 23 publicações selecionadas, totalizando 1.099 pacientes, foram organizadas numa tabela para análise sistemática.

Resultados Controle satisfatório da dor foi observado em 70,1\% dos casos, sendo que os melhores resultados foram encontrados em pacientes com lesão dos plexos braquial/lombossacro (70,8\%), e os piores, em pacientes com dor neuropática do nervo trigêmeo (40\% a 67\%).

Discussão A maioria dos artigos publicados encontrou ótimos resultados no controle da dor crônica, principalmente na dor relacionada à lesão de plexos. As complicações são raras, podendo ser minimizadas com o emprego das novas tecnologias de monitoração intraoperatória e imagem existentes.

Conclusão A drezotomia pode ser considerada uma ótima alternativa para o tratamento da dor crônica, especialmente em pacientes que não toleram os efeitos colaterais das medicações utilizadas no manejo clínico ou apresentam dor refratária.

\section{Introduction}

Neurosurgical procedures should be considered as a possible treatment for chronic pain refractory to pharmacotherapy and other treatments. ${ }^{1}$ Over 100 million adults in the United States are afflicted with chronic pain conditions by different causes (chronic diseases, peripheral nerve disorders and primary pain disorders) that play an important role in the patient's quality of life. ${ }^{2,3}$

Chronic neuropathic pain seems like a disease in itself, without any benefit or protective significance that characterizes the role of nociceptive pain in the human body. This illness imposes economic burdens to individuals and society, which can be observed in studies that suggest that patients with chronic pain experience worse health-related quality of life than the general population. ${ }^{4-6}$ Moreover, some epidemiological studies have also reported the negative effect that chronic pain has on health conditions, since it can be associated with more symptoms of anxiety and depression, and poorer sleep quality. ${ }^{7}$

The lesion of the dorsal root entry zone (DREZ) is considered an effective procedure to treat this type of pain. The goal of DREZ lesioning is to create a selective destruction of neurons and fibers that enter the DREZ and, by this mean, cut off the pain circuit and relieve the symptoms. ${ }^{8}$ The idea for the DREZ operation came to be in the early 1970's, after the introduction of the gate-control theory by Melzack and Wall in 1965. It was discovered that electrical stimulation was able to reduce certain types of pain. Thus, it became clear that the modulation of DREZ was important to understand the pain mechanisms. ${ }^{9}$ The first surgical attempts were made in 1972 to determine whether a destructive procedure in the
DREZ was feasible, safe and effective. This procedure was described as microsurgical DREZ-otomy (MDT), and it consisted of an incision and bipolar coagulations performed ventrolaterally at the entrance of the rootlets into the dorsolateral sulcus. The lesion penetrates the lateral part of the DREZ and the medial part of the tract of Lissauer, extending down to the apex of the dorsal horn. The latter is recognized under the surgical microscope by its brownishgray color. The typical lesion is $2 \mathrm{~mm}$ deep, and it is made at a $45^{\circ}$ angle medially and ventrally. ${ }^{10}$

Recently, other types of DREZ-lesioning techniques have been described to better achieve the expected results regarding the symptoms of the patient symptoms. Hence, the aim of the present study is to clarify, by a literature review, the results with different DREZ operation techniques to treat conditions involving neuropathic pain.

\section{Methods}

The PubMed, MEDLINE and LILACS databases were searched for manuscripts related to the DREZ operation. All relevant articles were included in the present review. Additionally, the reference sections of these articles were evaluated, and papers that provided important information regarding the subject were included. The results and conclusion of these articles were summarized in a chart. All types of studies were accepted, including other literature reviews. Articles that did not provide data regarding the effectiveness of the technique were not included. The selection protocol followed the flowchart in - Fig. 1. 


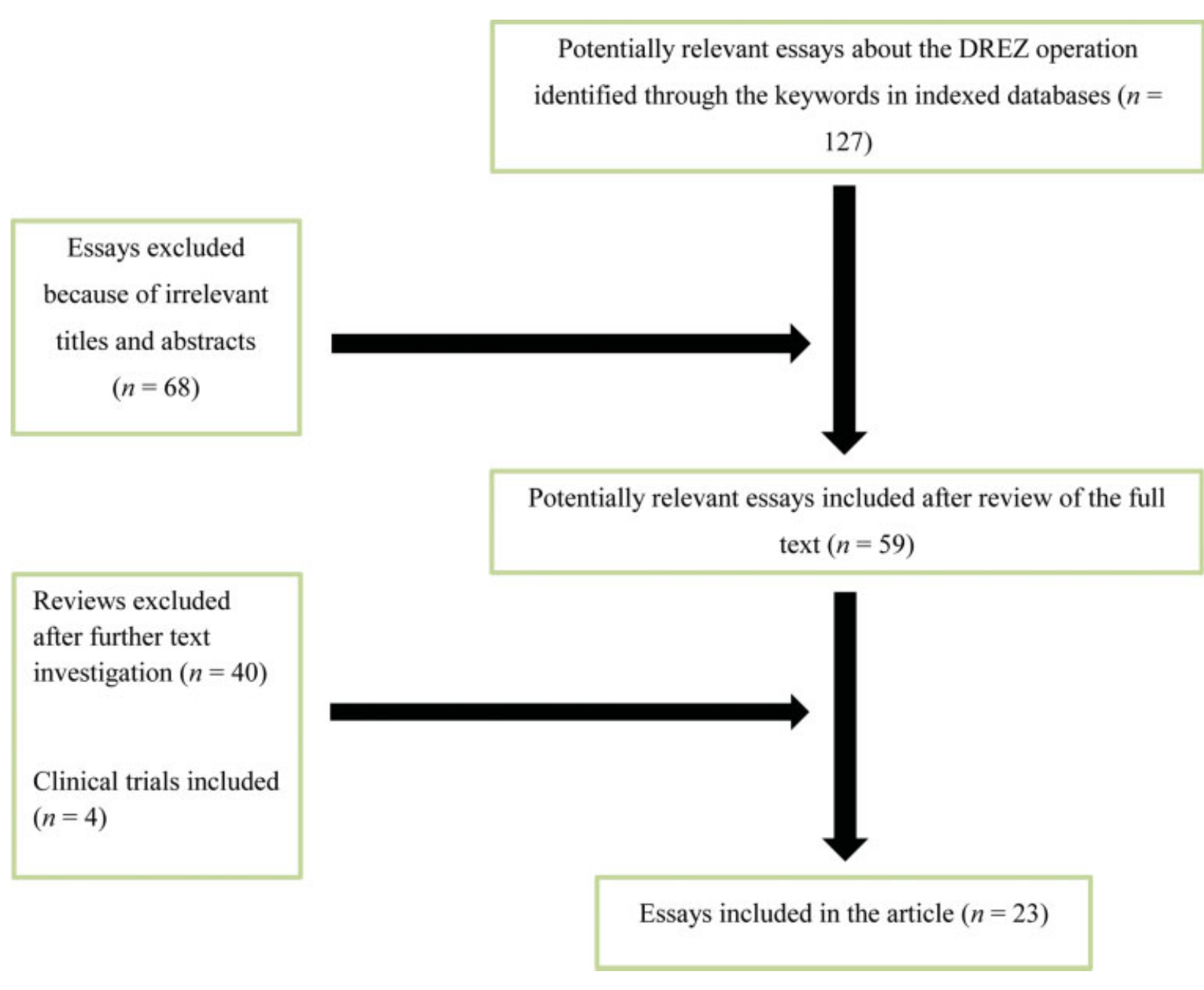

Fig. 1 Selection of articles.

\section{Results}

In total, 23 articles were included in the present review, totalizing 1,099 patients. The articles retrieved were written between 1986 and 2017. All data collected was summarized in -Table 1, including the conclusion, year and number of patients evaluated.

Out of the 23 articles, 10 performed the procedure for the improvement of chronic pain related to spinal cord injury, 4 , due to phantom pain, 13 , due to lesion of the brachial or lumbosacral plexuses, 4 , due to postherpetic neuralgia, 2 , due to cauda equina lesion, 3, due to hyperspastic states, 3, due to facial pain of multiple causes, 3 , due to peripheral nerves, 1 , due to deafferentation pain syndromes, and 2 for the control of cancer pain ( - Table $\mathbf{1}$ ).

For cervical DREZ lesioning, the highest percentage of good or excellent pain relief was found regarding cancer pain, hyperspastic states and cervical root avulsion. Plexus injuries, spinal cord injury, peripheral nerve injury and hyperspastic states were the etiologies related to the best results with conus medullaris DREZ lesion (-Table $\mathbf{1}$ ).

Nucleus caudalis DREZ lesion was the technique with the fewer number of patients $(n=41)$. All of them underwent surgery due to facial pain. The median percentage of good or excellent pain relief was of $60 \%$ (range: $40 \%$ to $73 \%$ ). Due to the small sample, these results may not show the actual effectiveness (-Table $\mathbf{1}$ ).

\section{Discussion}

\section{Considerations Regarding the Nonsurgical Management of Pain}

There is a vast range of pharmacological and nonpharmacological treatments available, including different mechanisms to control the pain pathway. In general, the pharmacological treatment is well tolerated by the patients; nevertheless, some of those treatments have potentially complicated side effects. $^{11}$

Antiepileptics, such as gabapentin and pregabalin, can be considered the most popular drugs to treat neuropathic pain. Pregabalin is approved for the management of pain due to diabetic peripheral neuropathy, postherpetic neuralgia, fibromyalgia, and neuropathic pain due to spinal cord injuries. ${ }^{11,12}$ Recently, the combination of intravenous ketamine and oral gabapentin was evaluated in a double-blinded, randomized, controlled trial on complicated neuropathic pain. This study showed an important improvement in pain scores in comparison to the placebo group. ${ }^{13}$ Anticonvulsants, like phenytoin 


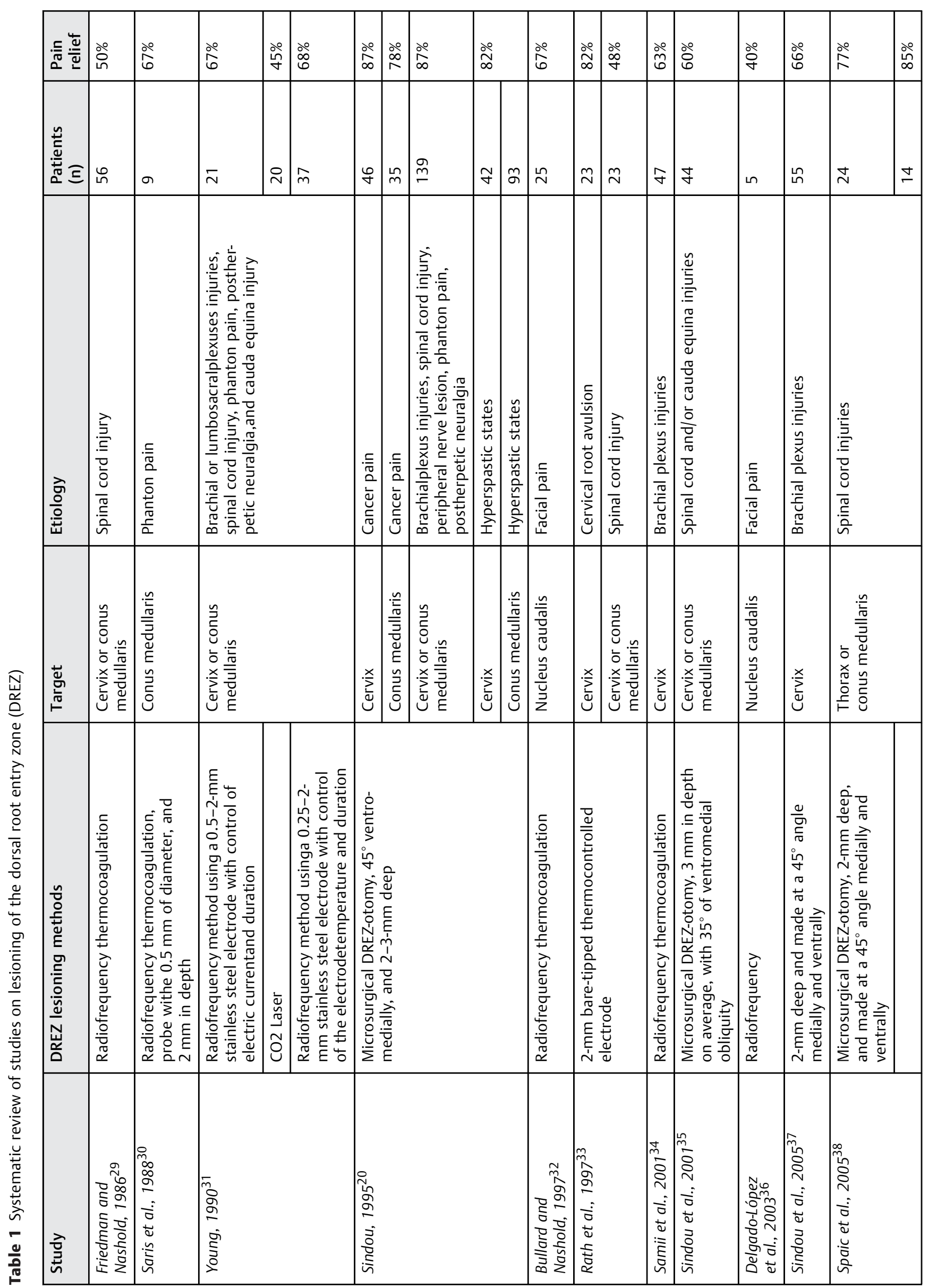




\begin{tabular}{|c|c|c|c|c|c|c|c|c|c|c|c|c|c|c|c|c|}
\hline 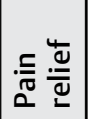 & ○ें & ठ̊ํ & ํํํ & 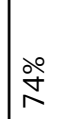 & 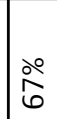 & $\stackrel{\circ}{\stackrel{2}{人}}$ & $\stackrel{\stackrel{一}{r}}{r}$ & $\frac{\stackrel{\circ}{\aleph}}{\stackrel{2}{*}}$ & ○ें & ठั่ & 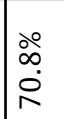 & $\underset{\infty}{\stackrel{\infty}{\infty}}$ & $\begin{array}{l}\stackrel{0}{\text { ஸे }} \\
\stackrel{0}{0} \\
0\end{array}$ & ஓ゚ & $\frac{\partial}{\stackrel{0}{0}}$ & ஓे \\
\hline
\end{tabular}

莣

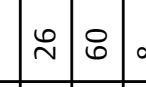

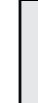

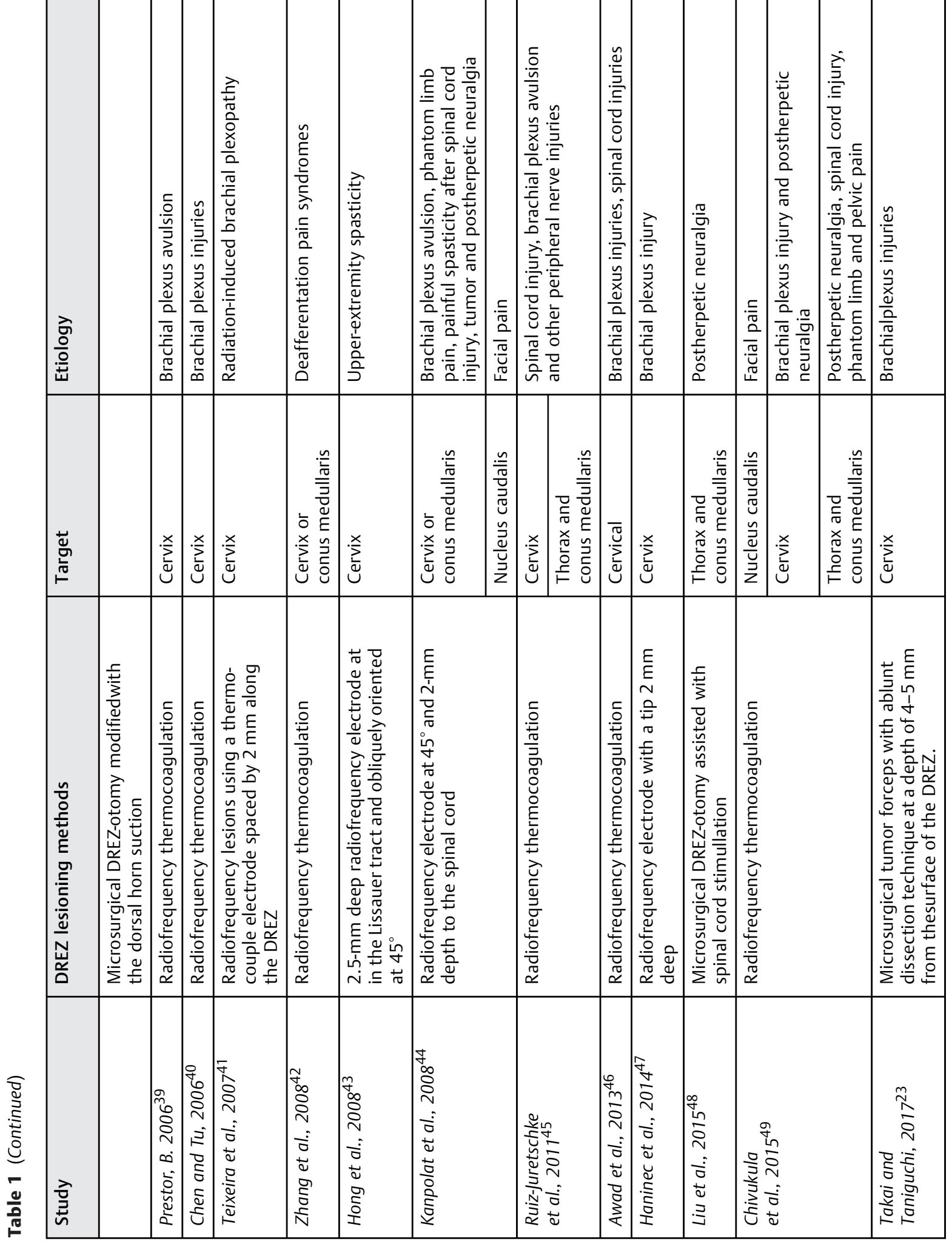


and carbamazepine, and other older-generation antiepileptic drugs (phenobarbital and valproic acid) have unfavorable metabolic and interaction profiles; thus, they are being less and less prescribed nowadays. ${ }^{14}$

Tricyclic antidepressants can modulate afferent pain pathways by increasing the levels of serotonin and norepinephrine in the central nervous system. Tricyclics have proven to be effective in the treatment of several chronic pain conditions, and can also be considered a first-line treatment in patients with neuropathic pain. Although these medications tend to be well-tolerated, various side effects are described, which are caused by the serotonergic, noradrenergic, and anti-histaminergic properties of these drugs. These adverse effects include: bladder retention, prolonged QT interval, sedation etc. ${ }^{15}$

Cannabinoids have received a lot of attention in recent years. This is due to studies that have shown their analgesic effects for non-cancerous pain. While cannabinoids tend to be well-tolerated with mild, transient side effects, more studies are required to prove the effectiveness and security of these drugs for the treatment of neuropathic pain. ${ }^{16,17}$

\section{Surgical Treatment}

Lesioning of the DREZ is a well-established surgical treatment for neuropathic pain. This procedure can be considered effective, safe and well-tolerated by most patients, justifying its frequent use.

Since the first description, DREZ lesioning evolved considerably. Created as a method for pain control for patients with chronic pain following brachial plexus avulsion, it can be used for many conditions, such as deafferentation pain, postparaplegia pain, painful spasticity, facial pain, cancer pain, postherpetic neuralgia, and brachial and sacral plexus avulsions.

The effectiveness of DREZ lesioning is based on the physiopathology of these diseases. They have in common neuropathic pain, which can be caused by imbalances between excitatory and inhibitory somatosensory signaling, alterations in ion channels, and variability in the way that pain messages are modulated in the central nervous system. ${ }^{18}$

The dorsal root of the spinal cord contains the axons from the primary afferent fibers originated in nociceptive receptors, which are responsible for the connection between the peripheral nervous system and the central nervous system. These neurons can ascend or descend a few vertebral levels through the tract of Lissauer. They enter the spinal cord through the dorsal root, where neurotransmitters are liberated, activating the second-order neurons located in the dorsal root. The second-order neurons ascend in the spinal cord through the lateral spinothalamic tract and spinal lemniscus until they reach the primary somatosensory cortex, where the information is processed. Considering these anatomophysiological aspects, it is simpler to understand why the destruction of the dorsal root has the potential to modulate neuropathic pain.

However, DREZ lesioning does not affect only pain fibers. The procedure has the ability of interrupting the unmyelinated and small myelinated fibers (considered tonigenic by their nociceptive input), as well as the large myelinated fibers going to the ventral horn, which are situated laterally and centrally in

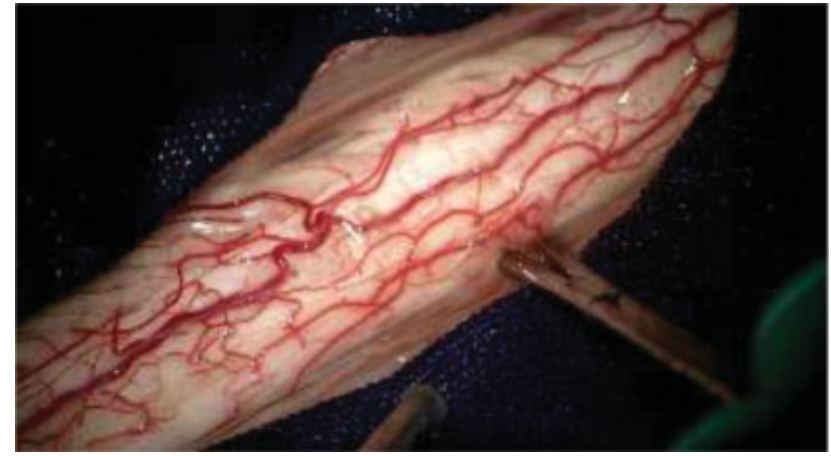

Fig. 2 Vessels along the sulcus.

the DREZ respectively. At the end, the targets for lesioning are the central portion of the dorsal rootlets, the lateral part of the tract of Lissauer, and mainly the first five dorsal layers of the dorsal horn, where the (deafferented) hyperactive neurons are located (which are involved in the physiopathology of neuropathic pain) or where the excitatory segmental circuitry of tone is situated (which is involved in spasticity).

The procedure is performed in prone position, and, depending on the level of the spinal cord, it may require a three-point cranial fixation device to align and immobilize the spine and skull. ${ }^{19}$ The laminectomy level should be determined based on the symptomatology, which generally follows specific dermatomes, demanding the bilateral destruction of fibers. Hemilaminectomies can be used for postherpetic neuralgia, or less frequently for single-dermatome pain or unstable spine. Patients undergoing a conus medullaris DREZ generally have laminectomies from levels D10 to L1, while patients undergoing nucleus caudalis or solitarius lesions undergo a small suboccipital craniectomy and Cl-C2 laminectomies. ${ }^{19}$

The dura mater and arachnoid are opened in the midline. Some structures, like the serpiginous vessels (-Fig. 2 ), may be present along the sulcus, so they must be retracted to enable a proper visualization of the region. Once the DREZ is located (-Fig. 3), the electrode can be introduced. Radiofrequency lesions are generally made at $75^{\circ} \mathrm{C}$ for 15 seconds, at $1 \mathrm{~mm}$ intervals along the intermediolateral sulcus, including the entire altered zone. The electrode should penetrate $2.0 \mathrm{~mm}$ deep and be held at a $25^{\circ}$ angle into the dorsal nerve rootlet ( - Fig. 4). The

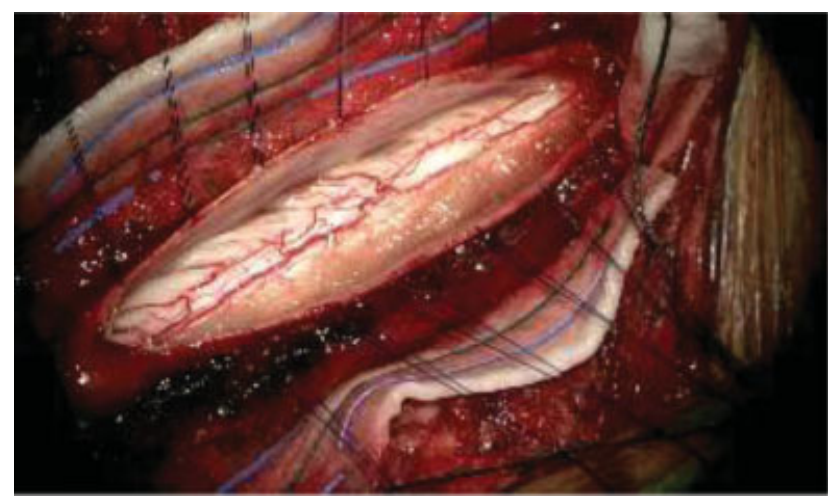

Fig. 3 Delimitation of the posterior medial sulcus (PMS). 


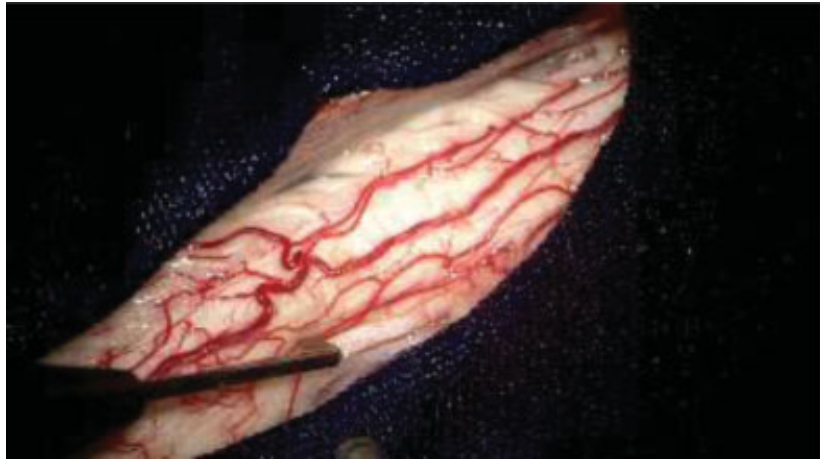

Fig. 4 DREZ lesioning using the electrode.

procedure is extended to the segments corresponding to the pain territory, including one level above and one below. ${ }^{20}$

Takai and Taniguchi ${ }^{23}$ described a posterior horn lesion using a microsurgical tumor forceps with a dissection technique at a depth of $4 \mathrm{~mm}$ to $5 \mathrm{~mm}$ from the surface of the DREZ. This new technique is based on recent findings regarding neuropathic pain suggesting the involvement of deeper layers of the gray matter of the spinal cord in pain conduction. ${ }^{22}$ This justifies the performance of deeper lesions on the posterior horn.

Another interesting fact regarding DREZ lesioning is the worse results found in conditions with diffuse pain. This seems to be related to the delimitation of the appropriate lesion level, which can be difficult depending on the case. Chun et al. ${ }^{21}$ described a modified DREZ lesioning procedure performed on both the complete injury zone (directly-injured cord level following spine injury) and the incomplete injury zone (indirectly-injured cord level identified on magnetic resonance imaging by signal change). This technique showed better results for diffuse pain than the original one, so they concluded that DREZ lesioning should be performed from the injured level up, including all abnormal rootlets above the level of the injury.

Sindou and Jeanmonod ${ }^{24}$ reported a series of 53 patients with harmful spasticity in one or both lower limbs. These patients underwent MDT for their painful state or abormal postures (either hyperextention or flexion). Spasticity and spasms decreased or were abolished in most patients, $75 \%$ and $88.2 \%$ of them respectively. Abolition of sensation was found in less than $10 \%$ of the patients. This study showed that MDT has the potential to significantly improve the quality of life of the patients. In 2017, Sitthinamsuwan et al. ${ }^{25}$ Published a study comparing DREZ lesioning and selective dorsal rhizotomy in fifteen spasticity patients. They concluded that DREZ lesioning is more effective to reduce spasticity, but more destructive than selective dorsal rhizotomy. Due to this, they suggested that DREZ lesioning should be preferred for bed-ridden patients, white selective dorsal rhizotomy, for ambulatory patients.

In 2016, Sindou and Georgoulis ${ }^{26}$ published a case series of 3 patients with focal dystonia who underwent cervical microsurgical DREZ-otomy. They noticed that all patients maintained the relief of hypertonia, the sustained abnormal dystonic postures remained absent, and most of the func- tional benefit was still present at the last follow-up. No patient suffered total loss of tactile sensation and proprioception. However, thermal and nociceptive sensations almost disappeared in all three patients. Moreover, patients did not develop neuropathic pain. ${ }^{26}$

The complications associated with DREZ lesioning can be separated into two different groups: over-lesioning and underlesioning. The most common complications regarding overlesioning are paralysis and dysesthesia, due to the destruction of adjacent pathways in the spinal cord (the lateral corticospinal, rubrospinal and spinocerebellar tracts, and the dorsal fasciculus). Genito-sphincterian deficits are another possible complication. ${ }^{19}$ On the other hand, ineffective pain control represents the under-lesioning complications.

To minimize the complications, it is imperative to choose the right spinal cord level, size of the lesion and angle of insertion. Henssen at al. ${ }^{27}$ conducted a study in 2019 to measure the angle between the DREZ and the posterior median sulcus (PMS). They made 11.7-T post-mortem magnetic resonance images and compared them to polarized light imaging microscopy to determine the fiber orientation of the dorsal horn tracts. The median angles between the DREZ and the PMS were of $40.1^{\circ}$ (left hemicord) and $39.8^{\circ}$ (right hemicord). With these results, they concluded that an insertion angle of $25^{\circ}$ should be recommended for DREZ lesioning.

Another study, conducted in 2019 by Monaco et al., ${ }^{28}$ described a real-time imaging technique to optimize DREZ lesioning using intraoperative ultrasound (US), which can determinate the exact location of the gray matter and dorsal horn. The US enables a correct positioning of the needle during the puncture, a proper angular adjustment, and a controlled depth.

\section{Conclusion}

Lesioning of the DREZ is an effective and safe procedure that should be considered a treatment for neuropathic pain due to diverse etiologies. Even though the pharmacological treatment is a possibility for the non-complicated cases, the surgical procedure is related to better results and fewer side effects. Thus, the treatment must be individualized, considering the quality of life and the decision of the patient.

\section{Conflict of Interests}

The authors have no conflicts of interest to declare.

\section{References}

1 Teixeira MJ, Haman C, Teixeira WGJ. Tratamento cirúrgico funcional da dor. Rev Med (São Paulo) 2001;80:276-289

2 Chivukula S, Tomycz ND, Moossy JJ. Paddle lead cervical spinal cord stimulation for failed neck surgery syndrome. Clin Neurol Neurosurg 2013;115(10):2254-2256

3 Deer TR, Skaribas IM, Haider N, et al. Effectiveness of cervical spinal cord stimulation for the management of chronic pain. Neuromodulation 2014;17(03):265-271, discussion 271

4 Jensen MP, Chodroff MJ, Dworkin RH. The impact of neuropathic pain on health-related quality of life: review and implications. Neurology 2007;68(15):1178-1182 
5 Smith BH, Torrance N, Bennett MI, Lee AJ. Health and quality of life associated with chronic pain of predominantly neuropathic origin in the community. Clin J Pain 2007;23(02):143-149

6 Inoue S, Taguchi T, Yamashita T, Nakamura M, Ushida T. The prevalence and impact of chronic neuropathic pain on daily and social life: A nationwide study in a Japanese population. Eur J Pain 2017;21(04):727-737

7 Attal N, Lanteri-Minet M, Laurent B, Fermanian J, Bouhassira D. The specific disease burden of neuropathic pain: results of a French nationwide survey. Pain 2011;152(12):2836-2843

8 Konrad P. Dorsal root entry zone lesion, midline myelotomy and anterolateral cordotomy. Neurosurg Clin N Am 2014;25(04): 699-722

9 Nashold BS Jr. Current status of the DREZ operation: 1984. Neurosurgery 1984;15(06):942-944

10 Sindou M. 1972Study of the dorsal root - spinal cord junction. A target for pain surgery. These Doctorat Medecine, Lyon 182

11 Hatch MN, Cushing TR, Carlson GD, Chang EY. Neuropathic pain and SCI: Identification and treatment strategies in the 21st century. J Neurol Sci 2018;384:75-83

12 Cardenas DD, Nieshoff EC, Suda K, et al. A randomized trial of pregabalin in patients with neuropathic pain due to spinal cord injury. Neurology 2013;80(06):533-539

13 Amr YM. Multi-day low dose ketamine infusion as adjuvant to oral gabapentin in spinal cord injury related chronic pain: a prospective, randomized, double blind trial. Pain Physician 2010;13(03):245-249

14 Finnerup NB, Gottrup H, Jensen TS. Anticonvulsants in central pain. Expert Opin Pharmacother 2002;3(10):1411-1420

15 Dworkin RH, O'Connor AB, Audette J, et al. Recommendations for the pharmacological management of neuropathic pain: an overview and literature update. Mayo Clin Proc 2010;85(03):S3-S14). Elsevier.

16 Lynch ME, Campbell F. Cannabinoids for treatment of chronic non-cancer pain; a systematic review of randomized trials. $\mathrm{Br} \mathrm{J}$ Clin Pharmacol 2011;72(05):735-744

17 Karst M, Salim K, Burstein S, Conrad I, Hoy L, Schneider U. Analgesic effect of the synthetic cannabinoid CT-3 on chronic neuropathic pain: a randomized controlled trial. JAMA 2003;290 (13):1757-1762

18 Colloca L, Ludman T, Bouhassira D, et al. Neuropathic pain. Nat Rev Dis Primers 2017;3:17002. Doi: 10.1038/nrdp.2017.2

19 Rawlings CE III, el-Naggar AO, Nashold BS Jr. The DREZ procedure: an update on technique. Br J Neurosurg 1989;3(06):633-642. Doi: $10.3109 / 02688698908992686$

20 Sindou M. Microsurgical DREZotomy (MDT) for pain, spasticity, and hyperactive bladder: a 20-year experience. Acta Neurochir (Wien) 1995;137(1-2):1-5

21 Chun H-J, Kim YS, Yi H-J. A modified microsurgical DREZotomy procedure for refractory neuropathic pain. World Neurosurg 2011;75(3-4):551-557. Doi: 10.1016/j.wneu.2010.12.005

22 Yang F, Zhang C, Xu Q et al. Electrical stimulation of dorsal root entry zone attenuates wide-dynamic-range neuronal activity in rats. Neuromodulation 2015;18(01):33-40, discussion 40

23 Takai K, Taniguchi M. Modified dorsal root entry zone lesioning for intractable pain relief in patients with root avulsion injury. J Neurosurg Spine 2017;27(02):178-184. Doi: 10.3171/2017.1.spine16234

24 Sindou M, Jeanmonod D. Microsurgical DREZ-otomy for the treatment of spasticity and pain in the lower limbs. Neurosurgery 1989; 24(05):655-670. Doi: 10.1227/00006123-198905000-00002

25 Sitthinamsuwan B, Phonwijit L, Khampalikit I, Nitising A, NuntaAree S, Suksompong S. Comparison of efficacy between dorsal root entry zone lesioning and selective dorsal rhizotomy for spasticity of cerebral origin. Acta Neurochir (Wien) 2017;159 (12):2421-2430. Doi: 10.1007/s00701-017-3322-x

26 Sindou M, Georgoulis G. Focal Dystonia in Hemiplegic Upper Limb: Favorable Effect of Cervical Microsurgical DREZotomy Involving the
Ventral Horn - A Report of 3 Patients. Stereotact Funct Neurosurg 2016;94(03):140-146. Doi: 10.1159/000446078

27 Henssen DJHA, Weber RC, de Boef J, et al. Post-mortem 11.7 Tesla Magnetic Resonance Imaging vs. Polarized Light Imaging Microscopy to Measure the Angle and Orientation of Dorsal Root Afferents in the Human Cervical Dorsal Root Entry Zone. Front Neuroanat 2019;13:66. Doi: 10.3389/fnana. 2019.00066

28 Monaco BA, Lopes AJM, Teixeira MJ. Ultrasound-Guided DREZotomy: Technical Note. Stereotact Funct Neurosurg 2019;97(02): 127-131. Doi: 10.1159/000500491

29 Friedman AH, Nashold BS Jr. DREZ lesions for relief of pain related to spinal cord injury. J Neurosurg 1986;65(04):465-469

30 Saris SC, Iacono RP, Nashold BS Jr. Successful treatment of phantom pain with dorsal root entry zone coagulation. Appl Neurophysiol 1988;51(2-5):188-197

31 Young RF. Clinical experience with radiofrequency and laser DREZ lesions. J Neurosurg 1990;72(05):715-720

32 Bullard DE, Nashold BS Jr. The caudalis DREZ for facial pain. Stereotact Funct Neurosurg 1997;68(1-4 Pt 1):168-174

33 Rath SA, Seitz K, Soliman N, Kahamba JF, Antoniadis G, Richter HP. DREZ coagulations for deafferentation pain related to spinal and peripheral nerve lesions: indication and results of 79 consecutive procedures. Stereotact Funct Neurosurg 1997;68(1-4 Pt 1):161-167

34 Samii M, Bear-Henney S, Lüdemann W, Tatagiba M, Blömer U. Treatment of refractory pain after brachial plexus avulsion with dorsal root entry zone lesions. Neurosurgery 2001;48(06): 1269-1275, discussion 1275-1277

35 Sindou M, Mertens P, Wael M. Microsurgical DREZotomy for pain due to spinal cord and/or cauda equina injuries: long-term results in a series of 44 patients. Pain 2001;92(1-2):159-171

36 Delgado-López P, García-Salazar F, Mateo-Sierra O, CarrilloYagüe R, Llauradó G, López E. Trigeminal nucleus caudalis dorsal root entry zone radiofrequency thermocoagulation for invalidating facial pain. Neurocirugia (Astur) 2003;14(01):25-32, discussion 32

37 Sindou MP, Blondet E, Emery E, Mertens P. Microsurgical lesioning in the dorsal root entry zone for pain due to brachial plexus avulsion: a prospective series of 55 patients. J Neurosurg 2005; 102(06):1018-1028. Doi: 10.3171/jns.2005.102.6.1018

38 Spaic M, Markovic N, Mikicic D, Ilic S, Milosavljevic I. The DREZ Surgical Treatment of chronic pain in traumatic paraplegia. Indian Journal of Neurotrauma 2005;2(02):111-116

39 Prestor B. Microcoagulation of junctional dorsal root entry zone is effective treatment of brachial plexus avulsion pain: long-term follow-up study. Croat Med J 2006;47(02):271-278

40 Chen HJ, Tu YK. Long term follow-up results of dorsal root entry zone lesions for intractable pain after brachial plexus avulsion injuries. Acta Neurochir Suppl (Wien) 2006;99:73-75

41 Teixeira MJ, Fonoff ET, Montenegro MC. Dorsal root entry zone lesions for treatment of pain-related to radiation-induced plexopathy. Spine 2007;32(10):E316-E319

42 Zhang XH, Li YJ, Hu YS, Tao W, Zheng Z. Dorsal root entry zone coagulation for treatment of deafferentation pain syndromes. Chin Med J (Engl) 2008;121(12):1089-1092

43 Hong JC, Kim MS, Chang CH, Kim SW, Kim OL, Kim SH. Long term results of microsurgical dorsal root entry zonotomy for upper extremity spasticity. J Korean Neurosurg Soc 2008;43(04): 182-185

44 Kanpolat Y, Tuna H, Bozkurt M, Elhan AH. Spinal and nucleus caudalis dorsal root entry zone operations for chronic pain. Neurosurgery 2008;62(03, Suppl 1):235-242, discussion $242-244$

45 Ruiz-Juretschke F, García-Salazar F, García-Leal R, et al. Treatment of neuropathic deafferentation pain using DREZ lesions; longterm results. Neurologia 2011;26(01):26-31 
46 Awad AJ, Forbes JA, Jermakowicz W, Eli IM, Blumenkopf B, Konrad P. Experience with 25 years of dorsal root entry zone lesioning at a single institution. Surg Neurol Int 2013;4:64

47 Haninec P, Kaiser R, Mencl L, Waldauf P. Usefulness of screening tools in the evaluation of long-term effectiveness of DREZ lesioning in the treatment of neuropathic pain after brachial plexus injury. BMC Neurol 2014;14(01):225
48 Liu MX, Zhong J, Zhu J, Xia L, Dou NN. Treatment of postherpetic neuralgia using DREZotomy guided by spinal cord stimulation. Stereotact Funct Neurosurg 2015;93(03):178-181

49 Chivukula S, Tempel ZJ, Chen CJ, Shin SS, Gande AV, Moossy JJ. Spinal and nucleus caudalis dorsal root entry zone lesioning for chronic pain: efficacy and outcomes. World Neurosurg 2015;84 (02):494-504 